\title{
Xplore $^{\circledR}$ mRNA Assays for the Quantification of IL-1 $\beta$ and TNF- $\alpha$ mRNA in Lipopolysaccharide- Induced Mouse Macrophages
}

\author{
S.W. Van Arsdell, K.P. Murphy, C. Pazmany, D. Erickson, C. Burns and M.D. Moody \\ Endogen, Inc., Woburn, MA, USA
}

BioTechniques 28:1220-1225 (June 2000)

\begin{abstract}
Because the accurate measurement of a number of cytokine mRNA transcripts provides valuable knowledge about cytokine gene regulation, we have developed the Xplore ${ }^{\circledR}$ assay for the quantification of cytokine mRNA. This microplate-based assay is rapid (under four hours), quantitative over three orders of magnitude and carries no risk of false-positive values from contamination with amplified target. Here, we describe the use of Xplore assays to measure the steady-state $m R N A$ levels of TNF- $\alpha$ and IL-1 $\beta$ produced by mouse WEHI and $J 774$ macrophage-like cell lines.
\end{abstract}

\section{INTRODUCTION}

Tumor necrosis factor- $\alpha$ (TNF- $\alpha$ ) and interleukin-1 beta (IL-1 $\beta$ ) are inflammatory cytokines that play important roles in the activation of the immune system following invasion of the host by endotoxin-producing Gram-negative bacteria. Macrophages, when exposed to lipopolysaccharide (LPS), produce large amounts of TNF- $\alpha$ and IL-1 $\beta$, which is released into the circulatory system. The expression of these cytokines is controlled by a variety of mechanisms, including the regulation of transcription, mRNA stability, translation, protein processing and secretion (1-10,13-17). Different studies have reported conflicting conclusions about the relative contribution of transcription and translation to $\mathrm{TNF}-\alpha$ regulation. It has been suggested that these different conclusions may be due in part to the different experimental methods used to measure TNF- $\alpha$ transcription rates and mRNA levels (15). Furthermore, few of these studies have quantified cytokine mRNA levels at multiple time points after LPS stimulation.
Here, we report the use of a novel and quantitative method, the Xplore ${ }^{\circledR}$ (Third Wave Technologies, Madison, WI, USA) mRNA assay $(11,12,18)$, to measure the steady-state mRNA levels of TNF- $\alpha$ and IL- $1 \beta$ produced by the mouse WEHI and J774 cell lines. The Xplore assay is based on a novel signalamplification system for the quantitative detection of nucleic acids $(11,12)$. It uses the endonuclease activity of a Cleavase ${ }^{\circledR}$ enzyme (Third Wave Technologies) to recognize a specific nucleic acid structure composed of two oligonucleotides that are hybridized to the mRNA target (Figure 1). The probes are designed so that the $3^{\prime}$-end of the upstream Invader ${ }^{\mathrm{TM}}$ probe (Third Wave Technologies) overlaps the $5^{\prime}$-end of the downstream signal probe. The endonuclease recognizes this complex and cuts the signal probe. The reaction is incubated near the melting temperature of the signal probe to permit the rapid exchange of hybridized signal probe. This turnover (hybridization, cleavage, dissociation of cleaved signal probe and replacement with an uncleaved signal probe) occurs rapidly so that multiple copies of the probe are cleaved for each copy of the target sequence without temperature cycling, and amplify the signal from the reaction.

The signal accumulates in a linear manner at a rate proportional to the amount of target in the original sample. These signal probe fragments are captured in a streptavidin-coated microwell (via biotin label on a capture probe with a sequence complementary to the signal probe). The captured signal probe fragments are then labeled with fluorescein-12-dUTP, which is added to the $3^{\prime}$-end of the cleaved signal probe by a DNA polymerase. The incorporated fluorescein-12-dUTP is detected by an anti-fluorescein antibody conjugated with alkaline phosphatase. The fluorescent detection signal is then produced by the reaction of the alkaline phosphatase with the substrate, which is converted to a fluorescent molecule. 


\section{MATERIALS AND METHODS}

\section{Growth and Stimulation of Cells}

Both J774A.1 (ATCC TIB67) and WEHI-3 (ATCC TIB68) cells were grown in RPMI 1640 media supplemented with $10 \%$ FCS, $1 \%$ Pen/Strep (Life Technologies, Rockville, $\mathrm{MD}$, USA), and $2 \mathrm{mM} \mathrm{L}$-glutamic acid at $37^{\circ} \mathrm{C}$ and $5 \% \mathrm{CO}_{2}$. The cells were plated at $2 \times 10^{6}$ cells/well in 6-well plates and stimulated with the addition of $5 \mu \mathrm{g} / \mathrm{mL}$ LPS. Cells were incubated overnight before the addition of $5 \mu \mathrm{g} / \mathrm{mL}$ LPS). At selected intervals, the media were removed and saved for ELISA analysis; cells in the plate were stored for RNA isolation by the addition of $1 \mathrm{~mL}$ TRIzoL ${ }^{\circledR}$ reagent (Life Technologies) and stored at $-70^{\circ} \mathrm{C}$.

\section{Total RNA Isolation}

Total RNA was isolated from cells using the TRIzoL reagent according to the manufacturer's specifications. RNA pellets were dissolved in $30 \mu \mathrm{L}$ RNAse-free water, and the concentration was determined by measuring the absorbance at $260 \mathrm{~nm}$. (Any potential impact of errors in RNA concentration determination on Xplore mRNA assay results was corrected by normalizing results to GAPDH mRNA concentrations.)

\section{Cytokine Concentration Determination}

The concentration of mouse TNF- $\alpha$ and IL-1 $\beta$ in culture media was measured using ELISA kits according to the manufacturer's instructions (Third Wave Technologies).

\section{Quantification of mRNA by Xplore Assays}

Mouse TNF- $\alpha$, IL- $1 \beta$ and GAPDH mRNA concentrations were measured using Xplore mRNA assays following the manufacturer's instructions. The Cleavase reactions were assembled in RNAse-free $200-\mu \mathrm{L}$ polypropylene tubes. Each $15-\mu \mathrm{L}$ reaction contained $500 \mathrm{ng}$ total RNA sample. The tubes were capped and then incubated in an oven at $54^{\circ} \mathrm{C}$ for $4 \mathrm{~h}$. After the Cleavase incubation, the reaction mixture was transferred to the wells of a streptavidin-coated 96-well plate for capture of the $5^{\prime}$ fragments of the cleaved signal probes in the plate using

\section{Probes for mouse IL-1 $\beta$ mRNA}

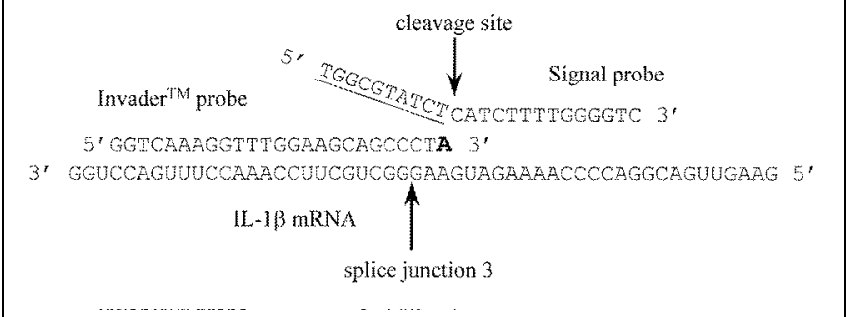

Figure 1. Probe design for the mIL-1 $\beta$ Xplore mRNA assay. The 3 ' base of the Invader probe (bold) invades the region where a base of the signal probe hybridizes to the target sequence. The Cleavase enzyme recognizes this complex and cuts the signal probe [the $5^{\prime}$ arm of the signal probe (underlined) is not complementary to the target]. a biotinylated capture oligonucleotide (which is complementary to the cleaved $5^{\prime}$-end of the signal probe). The cleaved probes were labeled with fluorescein-dUTP using a DNA polymerase that extended the $3^{\prime}$-end of the cleaved fragment on the capture probe template in a 15 -min incubation at $37^{\circ} \mathrm{C}$.

The plate was washed three times to remove any nonhybridized components. The fluorescein label was detected by adding $100 \mu \mathrm{L}$ anti-fluorescein-alkaline phosphatase antibody conjugate and incubating for $15 \mathrm{~min}$ at $37^{\circ} \mathrm{C}$. The excess antibody was removed by washing the plate three times. Bound antibody was detected by adding $100 \mu \mathrm{L}$ AttoPhos ${ }^{\mathrm{TM}}$ reagent (JBL Scientific, San Luis Obispo, CA, USA), and the plate was incubated for $30 \mathrm{~min}$ at $37^{\circ} \mathrm{C}$. The fluorescence was measured on a Cytofluor ${ }^{\circledR}$ plate reader (PE Biosystems, Foster City, CA, USA) $($ excitation $=450 / 50$, emission $=580 / 50$, gain $=50$, reads $/$ well $=10$ and temperature $=37^{\circ} \mathrm{C}$ ).

Standard curves for the assays were run with known amounts of TNF- $\alpha$, IL- $1 \beta$ or GAPDH in vitro-synthesized mRNA transcripts that were provided in the Xplore mRNA quantification kit. The signal from these standards was used to calculate the concentrations of the mRNA targets in the samples. The values shown are the averages of duplicate samples (Figure 3). The reported concentrations of IL-1 $\beta$ and TNF- $\alpha$ mRNA were normalized to the concentration of GAPDH mRNA present in those samples (determined by an Xplore assay for mouse GAPDH mRNA; data not shown). This was done by multiplying the uncorrected cytokine mRNA concentration by the time zero GAPDH mRNA concentration and then dividing that value by the time " $\mathrm{X}$ " GAPDH mRNA concentration.

\section{Northern Blot Analysis of mRNA}

Northern blot analysis of TNF- $\alpha$ and IL- $1 \beta$ mRNA was performed on $5 \mu \mathrm{g}$ samples of total RNA using Northern Max-Gly ${ }^{\mathrm{TM}}$, Strip-Ez RNA ${ }^{\mathrm{TM}}$, BrightStar Psoralen-Biotin ${ }^{\mathrm{TM}}$ and BrightStar BioDetect ${ }^{\mathrm{TM}}$ kits according to the manufacturer's instructions (Ambion, Austin, TX, USA).

\section{RESULTS}

As predicted from the results of previous studies (1-10, 13-17), the macrophage-like cell lines WEHI and J774 responded to stimulation with LPS by producing TNF- $\alpha$ and IL-1 $\beta$ mRNA and protein (Figures 2 and 4). The Xplore assays provided accurate quantitative detection of cytokine mRNA, and this revealed new information pertaining to the regulation of these cytokines in these cell types.

\section{TNF- $\alpha$ Regulation}

WEHI cells responded to LPS by increasing the level of TNF- $\alpha$ from a baseline level of 1 amol (in $500 \mathrm{ng}$ total RNA) to 3.6 amol within $30 \mathrm{~min}$. The steady-state level of TNF- $\alpha$ mRNA continued to increase, reaching a peak of 52 amol at 4 $\mathrm{h}$ after stimulation (Figure 2, B and 3). The quantitative values obtained using the Xplore mRNA assay correlated well with the results from the Northern blot analysis of TNF- $\alpha$ mRNA in the same samples (Figure 2C). Although the time course of TNF- $\alpha$ mRNA production was similar for both WEHI and J774 cells (detectable increases by $30 \mathrm{~min}$ and peaking at $4 \mathrm{~h}$ ), J774 cells produced over four times more 
TNF- $\alpha$ mRNA than WEHI cells (227 vs. 52 amol in $500 \mathrm{ng}$ total RNA) (Figure 2, A and B). If the efficiency of translational or post-translational processes was the same in $\mathrm{J} 774$ and WEHI cells, we would predict that the amount of TNF- $\alpha$ protein secreted by the $\mathrm{J} 774$ cells should be at least four times higher than that of the WEHI cells. However, the peak level of TNF- $\alpha$ protein secreted by the J774 cells was only twice that of the WEHI cells (3300 pg/mL vs. $1600 \mathrm{pg} / \mathrm{mL})$.

\section{IL-1 $\beta$ Regulation}

Xplore mRNA analysis of IL-1 $\beta$ mRNA in the WEHI cell total RNA samples showed that IL-1 $\beta$ mRNA levels did not increase until $1 \mathrm{~h}$ after induction, reached a peak level of 156
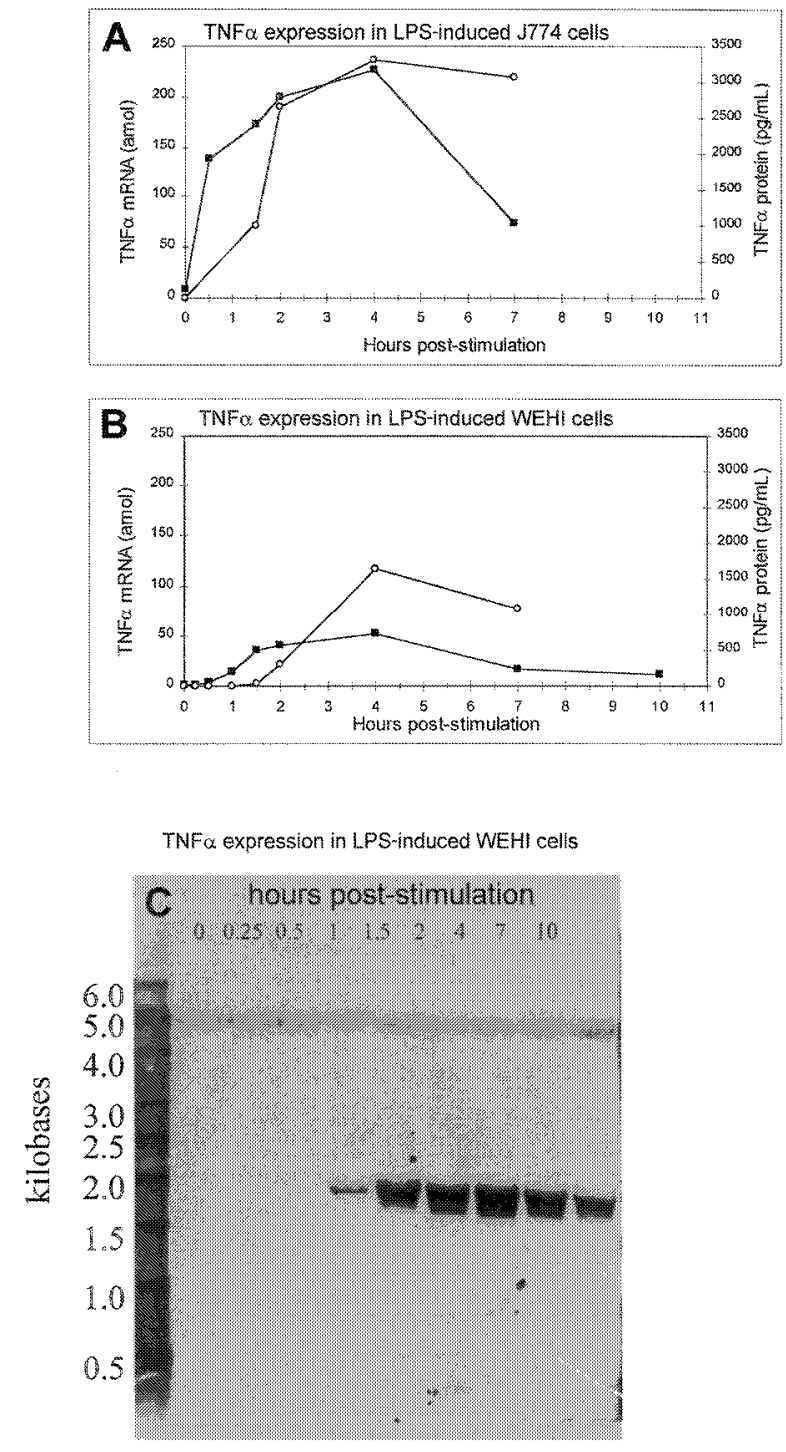

Figure 2. Quantification of TNF- $\alpha$ mRNA and protein produced by WEHI and J774 cells after stimulation with LPS over time. See Materials and Methods section for details. (A) Xplore assay analysis of TNF- $\alpha$ mRNA, and ELISA measurement of protein produced by LPS-stimulated J774 cells (ם, mRNA; O, protein). (B) Xplore assay analysis of TNF- $\alpha$ mRNA and ELISA measurement of protein produced by LPS-stimulated WEHI cells ( $\mathbf{\square}$, mRNA; O, protein). (C) Northern analysis TNF- $\alpha$ mRNA produced by LPS-stimulated WEHI cells. amol at $7 \mathrm{~h}$ and remained unchanged at $10 \mathrm{~h}(159 \mathrm{amol})$ (Figure 4B). These quantitative values correlated well with the results from Northern blot analysis of IL- $1 \beta$ mRNA in the same samples (Figure 4C). The WEHI cells produced more IL-1 $\beta$ mRNA than the J774 cells (132 vs. 85 amol in $500 \mathrm{ng}$ total RNA at $4 \mathrm{~h}$ after induction) (Figure 4, A and B). Because of the greater abundance of IL-1 $\beta$ mRNA in the WEHI cells, we predicted that the WEHI cells would produce more IL-1 $\beta$ protein. However, the $\mathbf{J} 774$ cells secreted nearly twice as much IL- $\beta$ protein as the WEHI cells (1255 vs. $621 \mathrm{pg} / \mathrm{mL}$ ). This difference between mRNA and protein levels suggests that the translational or post-translational processes are regulated differently in J774 and WEHI cells.

\section{DISCUSSION}

The Xplore mRNA assays provided accurate quantification of the steady-state levels of IL- $1 \beta$ and TNF- $\alpha$ mRNA. This quantitative measurement revealed information about the regulation of these cytokines that would be difficult to obtain with other mRNA analysis methods such as Northern analysis. The effective dynamic range of the Xplore assay was larger than that of a single X-ray film exposure of the Northern blot (Figures 2C and 3). An increase of TNF- $\alpha$ mRNA from 1 amol to 3.6 amol was observed 30 min after treatment of the WEHI cells with LPS, yet no band corresponding to TNF- $\alpha$ mRNA is seen in the lane of the Northern blot containing the 30-min sample, even when the 4-h peak sample band produced a strong exposure.

Both the J774 and WEHI cell lines are described as macrophage-like cells, and it might be predicted that these cell lines would regulate the production of inflammatory cy-

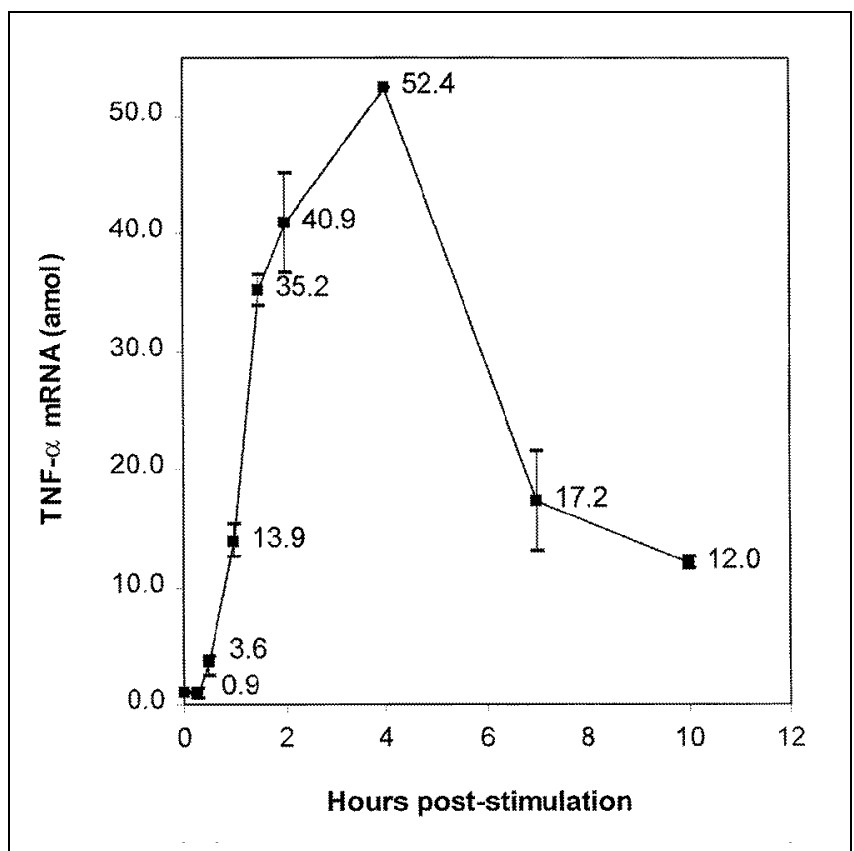

Figure 3. Xplore assay analysis of TNF- $\alpha$ mRNA produced by LPSstimulated WEHI cells over time (data shown in Figure 2B is replotted with an expanded $\mathbf{Y}$-axis). The average value of replicate samples is plotted (error bars represent the range of values of the duplicates). The amount of TNF- $\alpha$ mRNA (in amol) detected in $500 \mathrm{ng}$ total RNA is indicated next to each time point. 
tokines in a similar manner. However, while both cell lines responded to LPS stimulation by producing IL- $1 \beta$ and TNF- $\alpha$, the $\mathrm{J} 774$ cells produced much more IL- $1 \beta$ protein per IL-1 $\beta$ message than the WEHI cells. This was not because of any general difference in mRNA translation efficiency between the two cell types, since the WEHI cells produced more TNF$\alpha$ protein per TNF- $\alpha$ message than J774 cells. The measurement of steady-state mRNA and protein levels supports the conclusion that these cytokines were regulated differently in the two cell lines.

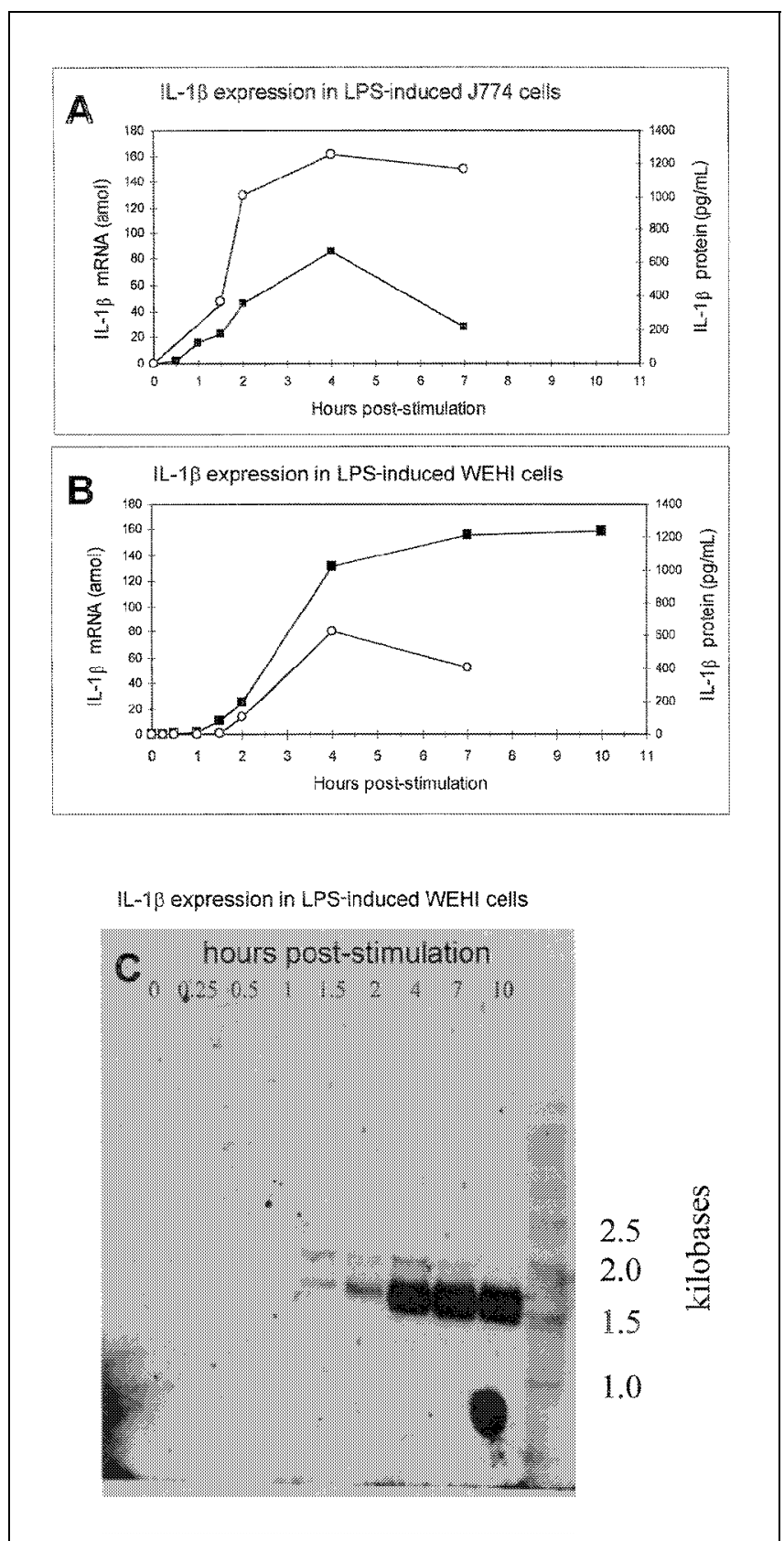

Figure 4. Quantification of IL-1 $\beta$ mRNA and protein produced by WEHI and J774 cells after stimulation with LPS over time. See Materials and Methods section for details. (A) Xplore assay analysis of IL-1 $\beta$ mRNA and ELISA measurement of protein produced by LPS-stimulated J774 cells ( $\square$, mRNA; O, protein). (B) Xplore assay analysis of IL- $1 \beta$ mRNA and ELISA measurement of protein produced by LPS-stimulated WEHI cells (ם, mRNA; O, protein). (C) Northern analysis IL-1 $\beta$ mRNA produced by LPS-stimulated WEHI cells.

\section{REFERENCES}

1.Collart, M.A., P. Baeuerle and P. Vassalli. 1990. Regulation of tumor necrosis factor alpha transcription in macrophages: involvement of four kappa B-like motifs and of constitutive and inducible forms of NF-kappa B. Mol. Cell Biol. 10:1498-1506.

2.Dinarello, C.A. and R. Schindler. 1990. Dissociation of transcription from translation of human IL-1-beta: the induction of steady state mRNA by adherence or recombinant $\mathrm{C} 5 \mathrm{a}$ in the absence of translation. Prog. Clin. Biol. Res. 349:195-204.

3.Drouet, C., A.N. Shakhov and C.V. Jongeneel. 1991. Enhancers and transcription factors controlling the inducibility of the tumor necrosis factor-alpha promoter in primary macrophages. J. Immunol. 147:1694-1700.

4.Fenton, M.J., B.D. Clark, K.L Collins, A.C. Webb, A. Rich and P.E. Auron. 1987. Transcriptional regulation of the human pro-interleukin 1 beta gene. Immunology 138:3972-3979.

5.Fenton, M.J., M.W. Vermeulen, B.D. Clark, A.C. Webb and P.E. Auron. 1988. Human pro-IL-1 beta gene expression in monocytic cells is regulated by two distinct pathways. J. Immunol. 140:2267-2273.

6.Han, J., T. Brown and B. Beutler. 1990. Endotoxin-responsive sequences control cachectin/tumor necrosis factor biosynthesis at the translational level. J. Exp. Med. 171:465-475.

7.Han, J., G. Huez and B. Beutler. 1991. Interactive effects of the tumor necrosis factor promoter and 3 '-untranslated regions. J. Immunol. 146:1843-1848.

8.Jarrous, N. and R. Kaempfer. 1994. Induction of human interleukin-1 gene expression by retinoic acid and its regulation at processing of precursor transcripts. J. Biol. Chem. 269:23141-23149.

9.Jongeneel, C.V., A.N. Shakhov, S.A. Nedospasov and J.C. Cerottini. 1989. Molecular control of tissue-specific expression at the mouse TNF locus. Eur. J. Immunol. 19:549-552.

10.Kaspar, R.L. and L. Gehrke. 1994. Peripheral blood mononuclear cells stimulated with C5a or lipopolysaccharide to synthesize equivalent levels of IL- $1 \beta$ mRNA show unequal IL-1 $\beta$ protein accumulation but similar polyribosome profiles. J. Immunol. 153:277-286.

11.Lyamichev, V., M.A.D. Brow and J.E. Dahlberg. 1993. Structure-specific endonucleolytic cleavage by eubacterial DNA polymerases. Science 260:778-783.

12.Lyamichev, V., A.L. Mast, J.G Hall, J.R Prudent, M.W. Kaiser, T. Takova, R.W. Kwiatkowski, T.J. Sander et al. 1999. Polymorphism identification and quantitative detection of genomic DNA by invasive cleavage of oligonucleotide probes. Nat. Biotechnol. 17:292-296.

13.Mijatovic, T., V. Kruys, D. Caput, P. Defrance and G. Huez. 1997. Interleukin-4 and -13 inhibit tumor necrosis factor- $\alpha$ mRNA translational activation in lipopolysaccharide-induced mouse macrophages. J. Biol. Chem. 272:14394-14398.

14.Puren, A.J., G. Fantuzzi and C.A. Dinarello. 1999. Gene expression, synthesis, and secretion of interleukin- 18 and interleukin- $1 \beta$ are differentially regulated in human mononuclear cells and mouse spleen cells. Proc. Natl. Acad. Sci. USA 96:2256-2261.

15.Raabe. T., M. Bukkrinsky and R.A. Currie. 1998. Relative contribution of transcription and translation to the induction of tumor necrosis factor- $\alpha$ by lipopolysaccharide. J. Biol. Chem. 273:974-980.

16.Schindler, R., B.D. Clark and C.A. Dinarello. 1990. Dissociation between interleukin-1 beta mRNA and protein synthesis in human peripheral blood mononuclear cells. J. Biol. Chem. 265:10232-10237.

17.Shakhov, A.N., M.A. Collart, P. Vassalli, S.A. Nedospasov and C.V. Jongeneel. 1990. Kappa B-type enhancers are involved in lipopolysaccharide-mediated transcriptional activation of the tumor necrosis factor alpha gene in primary macrophages. J. Exp. Med. 171:35-47.

Address correspondence to Dr. Mark D. Moody, Endogen, Inc., 30 Commerce Way, Woburn, MA 01801-1059, USA. Internet:mmoody@endogen.com 